\title{
A CONCEPTUAL FRAMEWORK FOR INTEGRATING INDUSTRY/CLIENT-SPONSORED PROJECTS INTO ONLINE CAPSTONE COURSES
}

\author{
Rana Khan \\ University of Maryland University College
}

Julie Hill

University of Maryland University College

\begin{abstract}
To address the growing need for incorporating experiential learning into online degree programs, this paper proposes a design framework that would integrate industry-sponsored projects into online capstone courses. The design could be applicable to any program at any institution. The research and data used to develop the framework was gathered from literature review and a survey of University of Maryland University College (UMUC) graduate programs. The proposed framework was tested in two capstone courses using industry/client sponsored projects in the author's disciplines as the first stage of testing of the model.
\end{abstract}

\section{KEYWORDS}

Capstone, design, framework, graduate, online, project, client/sponsor, industry partner

\section{INTRODUCTION}

The authors used research and data from a literature review and a survey of UMUC graduate programs to develop a framework that incorporates industry-sponsored projects into online capstone courses. Most master's programs at UMUC end with a capstone course. Several of the capstone courses use industry/client sponsored projects, including the ones in the authors' respective disciplines, biotechnology and public relations. The proposed framework was tested with in the biotechnology and public relations programs as the first stage of testing of the model.

Integrating hands-on experience and/or experiential learning into the curricula of degree programs is gaining ground in academic programs in part because academicians and employers alike see value in providing students with practical opportunities to demonstrate proficiency in their fields of study. To meet this need, capstone courses that incorporate some form of experiential learning opportunity have emerged as a mainstay of many college and university programs, primarily at the senior undergraduate level. Capstone courses provide practical experience in a variety of ways, including internships, cooperative education opportunities, simulations, or projects. In some cases, academic programs utilize real-world industry/client-sponsored projects as the foci of the students' final work products. Institutions form partnerships with employers, the sponsors receive low- or no-cost project work, and students leave with a portfolio of work and professional connections that could lead to employment opportunities.

Regardless of the specific design of the practical capstone courses, a common denominator is to provide a culminating experience that allows students to demonstrate mastery of knowledge and skills gained through prior classwork during the degree program. Kelly [1] emphasizes the need to pay special attention to the development and design of capstone courses such that they provide the right culminating 
experience with reflection, integration, and summation of the knowledge and skills gained through the program.

As one of the first institutions in the world to offer distance education opportunities, UMUC has established itself as a leader in the field. A public university offering primarily online programs at both graduate and undergraduate levels, UMUC reported a student headcount of 59,974 in fall 2012 with 45,868 undergraduate and 14,106 graduate students. Most of the 18 graduate programs at UMUC include a set of required core courses followed by a set of specialization-specific courses. UMUC's focus is on providing students with a strong and workforce-relevant curriculum. While face-to-face teaching environments allow for fewer obstacles in providing experiential learning opportunities for students, UMUC has long recognized the value of integrating hands-on experiential learning activities and has adapted traditional face-to-face teaching and learning methods to the online environment to accomplish this goal.

\section{LITERATURE REVIEW}

A number of researchers have explored the value of incorporating client-based projects into capstone courses. Most of the research has focused on undergraduate degree programs and capstone courses offered in a traditional face-to-face learning environment.

Applied science and engineering programs in particular make extensive use of capstone projects that often incorporate work with real industry/client-sponsored projects [2,3]. Bruhn and Camp [4] highlighted the impact on all stakeholders of an engineering capstone course for college seniors developed in consultation with the industry. The faculty worked with students to assign members and projects to each team and provided guidelines on how to produce a deliverable that would be useful to the sponsor. The course employed a three-tiered monitoring system that included student self-monitoring, a corporate mentor, and faculty monitoring. The process allowed every team member to pull equal weight and perform a fair share of the tasks. At the conclusion of the course, all students felt better equipped to move on to a job, and there was a consensus that this course was invaluable to the curriculum.

Gorka, Miller, and Howe [5] found that for capstone projects with industry partners to be successful, industry participation is essential, confidentiality must be maintained, and there should be an industry representative or liaison. Berheide [6] explored the potential of capstone courses for assessing student learning and found considerable support for such assessments if the course is properly designed and executed, making capstone courses ideal summative assessment tools [7].

A consortium of faculty at the Western Michigan University's College of Engineering and Applied Sciences was tasked with designing a capstone with a uniform experience across the college [3]. They shared design expectations and evaluation materials and then identified common needs and developed common activities. The outcome was a multidisciplinary capstone course designed to include topics such as written and oral communication, teamwork, patent issues, and intellectual property that were applicable across the college. In addition, common evaluation materials for proposal, presentation, report, and literature review were developed.

Gorman [8] wrote about the best practices he identified in designing a capstone course for an undergraduate program in operations management. This course is offered in a six-credit, two-semester format. In the first semester, students complete a one-credit requirement of proposal development based on client needs. In the second semester, each student team earns five credits by implementing the proposal. Conclusions drawn from this capstone course over a period of eight years suggest that a consulting-style project provides a unique and rewarding experience for students, and the project is equally valuable to the clients. The key determinants of success include a well-defined scope of the project, deep commitment of faculty and the client, simplicity of approach used to address the problem, reliance on the facts provided, and excellent written and oral presentation skills of the students. 
At the graduate level, there is limited research on the design of capstone courses that, similar to undergraduate capstones, exist in a variety of forms. Although fewer graduate than undergraduate programs incorporate industry/client-sponsored projects, there is growing recognition and evidence that such projects have significant benefits for students, the academic programs and institutions, and the industry partners/clients $[4,5,9]$.

Within this body of research, some educators outline how their institutions' capstone courses are designed and what seems to work for them Hagan [13] provided an example of a client project model in an online graduate program. The paper focused on the design of a project model that the author used to successfully integrate hands-on experience in a business course. A client project secured by the instructor was integrated into a marketing course on strategic communication and public relations in the MBA program at a private non-profit business college. Each student team applied their knowledge by developing a public relations campaign for a non-profit organization. The teams developed a work plan and provided a progress report, final report, and presentation to the client. Team members evaluated each other and the client offered feedback to the teams at the end of the project.

Other educators suggested that they follow some best practices, including clearly identifying project expectations and deliverables upfront, ensuring industry and faculty leads are committed to the project and the course is well-structured. [3]. Still others proposed a set of best practices to follow when real client projects are used in a capstone course [14, 15, 16]. For example, Estell and Hurtig [14] described the capstone course in the Electrical and Computer Engineering and Computer Science department at Ohio Northern University. The department "adopted both an industry-based project management standard and a corresponding corporate project management documentation practice as an operational framework" [14]. The department also employed a project review board made up of faculty with specific expertise related to the projects and formative and summative assessments based on common rubrics.

Research to date has found only a few professional associations and accrediting boards that recommend/require the inclusion of a capstone course as part of a higher education curriculum. Of those, a handful specify the inclusion of some type of integrative, experiential capstone: the Accreditation Board for Engineering and Technology, the Commission on Accreditation for Health Informatics and Information Management Education, the Commission on Accreditation Healthcare Management Education, the Society for Human Resource Management, and the Commission on Public Relations Education.

Despite growing interest in and use of industry partners in capstone courses, what has yet to emerge is a single, unified framework that integrates the various best practices and success factors researchers have identified. We believe that developing a framework that considers the range of variables available in creating an industry-partnered capstone course would assist academic institutions with the design or revision of these experiential and competency-based courses.

Considering that more and more schools are moving to online delivery, and increasing numbers of students are taking classes online [17], it is important to consider the options for providing a real-life learning experience to students in these classes.

\section{CAPSTONE COURSES AT UMUC}

UMUC offers 18 different master's degree programs in five departments as shown in figure 1. Within each department are multiple master's degrees and various specializations; some programs are structured around six-credit courses and others have mostly three-credit courses. Total degree credits range from 3642 , depending on the program, though most feature a combination of core and specialization courses. 


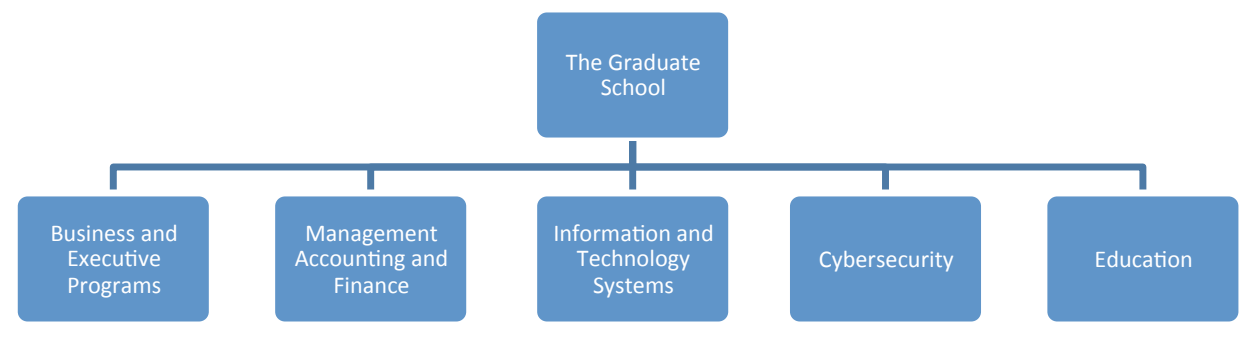

Figure 1. UMUC Graduate School Departments

The capstone course may be part of the core or specialization programs. In either case, the purpose is to integrate and apply the learning that has taken place up to that point. However, the approach used to provide the culminating experience varies.

\section{A. Survey of UMUC Graduate Programs}

A fall 2012 survey of graduate program directors included all 18 graduate programs at UMUC and identified (1) whether the programs were offering a capstone experience and (2) how the capstone experience was offered.

Survey results found that $89 \%$ (16) of the programs offer a capstone course. The types of capstone courses at UMUC are listed in table 1. Courses in the "Other" category involve research papers, short assignments, or a combination of several activities.

\begin{tabular}{|l|l|}
\hline Projects with Industry & $28 \% / 5$ \\
\hline Projects (Hypothetical) & $17 \% / 3$ \\
\hline Case Study & $17 \% / 3$ \\
\hline Simulation & $11 \% / 2$ \\
\hline Seminar & $5.6 \% / 1$ \\
\hline Other & $22 \% / 4$ \\
\hline
\end{tabular}

Table 1. Types of Capstone Projects within UMUC Graduate School Programs

Across all the programs that offer a capstone course project, there was an almost even split between offering it as a group project, individual project, or a combination of the two. Approximately $35 \%$ of programs use a project as a course centerpiece. Only 5 of the 18 programs/specializations offer a capstone project with the industry. Of these, two are part of the core courses and the remaining three are included in the specialization courses. The authors' research and experience found that several factors contribute to the successful integration of an industry-sponsored project into the capstone course. These factors include a very structured course, a robust and sustainable approach to soliciting projects from the industry, course design that would ensure accountability and timeliness, clearly outlined expectations for the companies and the students, a fair and comprehensive evaluation of student learning and a product that fulfills the goals of the project. 


\section{FRAMEWORK FOR DESIGN OF CAPSTONES WITH INDUSTRY- SPONSORED PROJECTS}

Integrating industry/client-sponsored projects into capstone courses is not without challenges, especially for large programs and those operating in asynchronous environments. Issues of scalability, varying degrees of deliverable quality, students' abilities to work with teams asynchronously and in different time zones, and the time/effort required to identify potential partners/clients with appropriate projects are all issues that must be addressed. A model or framework that incorporates best practices and is flexible enough to adapt to the needs of a program can be useful to institutions considering the development of a capstone course or modifying an existing one.

Based on the UMUC capstone course survey results and literature review, we developed a framework as illustrated in figure 2. This framework has four components that we found to be essential in the successful design and implementation of an industry-sponsored capstone project. Each component encompasses elements that provide options and issues to consider. Taken together, these elements and issues determine the ultimate nature of the project and the student experience.

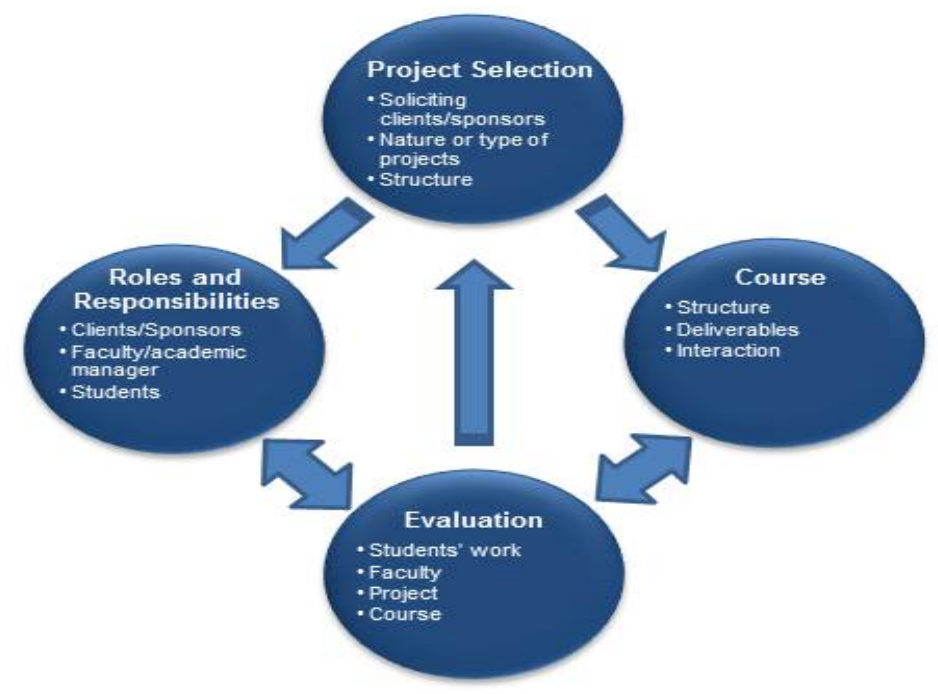

Figure 2. Proposed Capstone Framework

The four components of the framework are interdependent, as shown by the arrows in figure 2 . The project selection process, including the nature of the project, determines the roles and responsibilities of the various stakeholders (students, faculty, and clients/sponsors) and the course design. Two components depicted in figure 2, Roles and Responsibilities and Course, affect the design of the evaluations. Evaluations lead to revision and changes in all components of the framework.

Table 2 provides a detailed tabular view of the framework, showing various capstone course options. Each component of the course is broken into several elements. The items specified under the Capstone Course Design Options section correspond to each element and are presented in columns to facilitate the selection of a design option. In cases where an element spans the entire category (e.g., Project goals align with course outcomes), the element is considered essential for all projects.

\begin{tabular}{|l|l|l|l|}
\hline Component & Elements & Capstone Course Design Options \\
\hline Projects & Solicitation & $\begin{array}{l}\text { Students generate clients/projects } \\
\text { following established criteria }\end{array}$ & Faculty member solicit/secure projects \\
\cline { 2 - 4 } & Nature or Type & Project goals align with course outcomes \\
\cline { 2 - 4 } & $\begin{array}{l}\text { No financial contributions from } \\
\text { client/sponsor }\end{array}$ & $\begin{array}{l}\text { Sponsor/client provides financial support to } \\
\text { institution, funds research, and/or pays fee }\end{array}$ \\
\hline
\end{tabular}




\begin{tabular}{|c|c|c|c|}
\hline & & $\begin{array}{l}\text { Problem based: students develop } \\
\text { proposals with or without } \\
\text { implementation }\end{array}$ & $\begin{array}{l}\text { Results based: implementation with outcomes } \\
\text { specified by client/sponsor }\end{array}$ \\
\hline & & $\begin{array}{l}\text { Confidentiality/privacy agreement(s) } \\
\text { not required }\end{array}$ & Confidentiality/privacy agreement(s) required \\
\hline & & Client is like a customer & Sponsor is like mentor or coach \\
\hline & Structure & \multicolumn{2}{|c|}{$\begin{array}{l}\text { The project scope has well defined goals and objectives that are realistic for the length } \\
\text { of the semester(s) }\end{array}$} \\
\hline & & Individual work & Team-developed work \\
\hline & & $\begin{array}{l}\text { Competitive: similar to a request for } \\
\text { proposal (RFP) process, students } \\
\text { compete to develop winning proposal } \\
\text { for same client }\end{array}$ & $\begin{array}{l}\text { Collaborative: Students work on team or } \\
\text { independent projects, but share ideas, assist } \\
\text { each other, and do not compete to submit a } \\
\text { winning proposal }\end{array}$ \\
\hline & & $\begin{array}{l}\text { More than one student or group works } \\
\text { on the same project }\end{array}$ & One person/team per project \\
\hline \multirow[t]{8}{*}{ Course } & \multirow[t]{3}{*}{ Structure } & One term/semester & Two or more terms/semesters \\
\hline & & One course & Two or more courses \\
\hline & & Majority of time focused on the project & $\begin{array}{l}\text { Project time augmented with lectures, } \\
\text { discussions, and additional readings }\end{array}$ \\
\hline & \multirow[t]{3}{*}{ Deliverables } & $\begin{array}{l}\text { Various types of assignments (research } \\
\text { paper, report, proposal, presentation, } \\
\text { quiz, exam, visual material, etc.) }\end{array}$ & $\begin{array}{l}\text { Single assignment, typically a research paper, } \\
\text { proposal, or report }\end{array}$ \\
\hline & & $\begin{array}{l}\text { Components due and graded } \\
\text { throughout the semester(s)/term(s) }\end{array}$ & $\begin{array}{l}\text { Majority of work due at the conclusion of the } \\
\text { semester(s)/term(s) }\end{array}$ \\
\hline & & $\begin{array}{l}\text { Students incorporate feedback into } \\
\text { final deliverable }\end{array}$ & $\begin{array}{l}\text { Informal feedback provided throughout the } \\
\text { semester without any graded components }\end{array}$ \\
\hline & \multirow[t]{2}{*}{ Interaction } & Asynchronous environment & Synchronous or face-to-face environment \\
\hline & & $\begin{array}{l}\text { Faculty member mediates interaction } \\
\text { between student and sponsor/client }\end{array}$ & $\begin{array}{l}\text { Students have direct interaction with } \\
\text { sponsor/client }\end{array}$ \\
\hline \multirow{5}{*}{$\begin{array}{l}\text { Roles and } \\
\text { Responsibilities }\end{array}$} & \multirow[t]{3}{*}{ Faculty } & Facilitator & Mentor \\
\hline & & $\begin{array}{l}\text { Reviews work before final submission } \\
\text { to the client }\end{array}$ & Provides ongoing guidance to student/teams \\
\hline & & $\begin{array}{l}\text { Establishes and enforces deadlines and } \\
\text { client expectations as outlined in the } \\
\text { client's project summary }\end{array}$ & $\begin{array}{l}\text { Establishes and enforces deadlines but client } \\
\text { manages own expectations for the project } \\
\text { goals }\end{array}$ \\
\hline & Client/ Sponsor & $\begin{array}{l}\text { Arms-length from students or interacts } \\
\text { minimally with students directly }\end{array}$ & $\begin{array}{l}\text { Works directly/closely with students, } \\
\text { including regular meetings and feedback }\end{array}$ \\
\hline & Students & $\begin{array}{l}\text { Each individual student is responsible } \\
\text { for all elements of the project }\end{array}$ & $\begin{array}{l}\text { Students work in teams with defined roles } \\
\text { (assigned or member negotiated) }\end{array}$ \\
\hline \multirow[t]{7}{*}{ Evaluations } & \multirow[t]{5}{*}{ Students' Work } & \multicolumn{2}{|l|}{ Grading rubrics } \\
\hline & & $\begin{array}{l}\text { Faculty member reviews work before } \\
\text { students' proposals are submitted to } \\
\text { the client/sponsor }\end{array}$ & $\begin{array}{l}\text { Client/sponsor reviews students' work } \\
\text { before it is submitted for grading }\end{array}$ \\
\hline & & Faculty grading & Client/sponsor evaluations \\
\hline & & Student self-evaluation & Team member evaluations \\
\hline & & Formative & Summative \\
\hline & Course/ Project & $\begin{array}{l}\text { Student evaluations using } \\
\text { questionnaires }\end{array}$ & $\begin{array}{l}\text { Client/sponsor evaluations using } \\
\text { questionnaires }\end{array}$ \\
\hline & Faculty & \multicolumn{2}{|c|}{ Student evaluations using questionnaires } \\
\hline
\end{tabular}

Table 2. Detailed Framework View

As illustrated in table 2, the proposed framework for designing capstone courses with industry-sponsored projects has four main components: Projects, Course, Roles and Responsibilities, and Evaluations. Additional details for each component follow.

\section{A. Projects}

The main component of the capstone course is a project with an industry partner or client. 


\section{Solicitations}

The first and critical part of the course is to secure projects from industry organizations.

a) Student identified: Asking students to identify and bring in projects that meet established criteria is a good option for a couple of reasons. First, it is more likely to be a project in which the student has a vested interest. Second, it lessens the demands on the faculty or program manager. However, this option could reduce the time to work on the project because the process only starts once the semester begins. Some form of advanced project approval before the start of a semester or term could provide students with more time to work on the project once the semester/term begins.

b) Faculty or program manager identified: Having the instructor or program manager secure the projects for students to select on the first day of class enables students to start right away. Repeat clients/sponsors, industry contacts, adjunct faculty who work in the industry, alumni, and contacts through professional organizations are all possible resources for projects. The substantial time commitment on the part of the instructor or program manager to secure projects before the start of the semester is a major challenge with this option.

\section{Nature or Type}

The type of project selected for an experiential capstone course must be appropriate to the goals of the program and must involve the following variables:

a) Project goals: Project goals should follow the outcomes established for the course. The outcomes in turn align to the program outcomes, which are mapped to the institution's outcomes.

b) Funded or unfunded projects: A particular project may receive financial support from the client and may or may not be supported by the client or sponsor in the form of a fee or financial support to the institution. In general, there are more cases of non-funded projects than funded projects.

c) Problem or results-based projects: Problem-based projects allow students to develop proposals with or without implementation. Results-based projects allow students to present and implement results based on outcomes specified by the client/sponsor.

d) Confidentiality/privacy: Depending on the nature or type of client and the work outlined in the project, it may be necessary and desirable for students to sign confidentiality agreements.

e) Client vs. sponsor role for industry partner: Defining the nature of the relationship with the industry partner is key to determining other critical elements of the course. As a client, the industry partner is generally only minimally involved in the students' work and does little more than respond to questions about the client organization or the project. As a sponsor, the industry partner takes an active role in working with students.

\section{Structure}

The capstone course involving industry partners could be structured or designed several different ways, depending on the goals of the program and the nature or types of projects selected.

a) Scope of work: It is essential to work with the industry partner to ensure the scope of work is appropriate for the students' level of performance and to ensure that the projects can be realistically accomplished in the prescribed length of time for the course.

b) Individual or team projects: The course can be structured such that each student works independently or as part of a team.

c) Competitive or collaborative: The course can be designed to provide a competitive environment to have students compete to submit the "winning" proposal determined by the client. In these cases, students work to develop proposals for the same client. The course can also be designed to have individuals or teams of students develop and/or implement projects on behalf of different clients to promote a much more collaborative environment.

d) Number of students per project: Depending on the project structure, it is possible to have an entire class work on one project or have students work individually or in teams on distinct and separate projects. 


\section{B. Course}

The overall course should have the following key elements that are essential in providing a successful and meaningful experience to the stakeholders.

\section{Structure}

There are several options for structuring the capstone course involving industry partners.

a) Length: The capstone course may be one or two semesters/terms in length.

b) Number of courses: If the course is two semesters in length, it may be split into two separate courses. For example, the first course could be focused on developing a proposal and the second course could be focused on implementing the proposal.

c) Percentage of project-focused time: The course may be centered on the project, which then carries more than $50 \%$ of the course grade, or the focus on the project may be a smaller part as one of several deliverables/activities.

\section{Deliverables}

The nature and type of deliverables students produce should be consistent with course goals and client/sponsor expectations.

a) Types of assignments: Depending on the nature of the project, instructors can incorporate a variety of graded assignments (e.g., exams, quizzes, reports, proposals, etc.) or have students focus on a single major deliverable (such as a paper, proposal, or report).

b) Assignment submittals: The number and nature of deliverables that students (individuals or teams) are asked to provide should ensure that the project is moving in the right direction at the right pace and with each individual doing a fair share of the work. A single graded deliverable at the end of the course or graded deliverables throughout the term/semester are options for assignments. For a team project, the most common use of assignments is a mix of individual and group contributions.

c) Timing and use of feedback: If the course includes multiple deliverables, students may have the opportunity to incorporate feedback into improvements on the final deliverable. In the case of a final major deliverable, students may only receive informal feedback throughout the project.

\section{Interaction}

Whether the class is asynchronous or face-to-face/synchronous has implications for how the course is designed and the roles and responsibilities established.

a) The interactions may be synchronous (conference calls, video meetings) between the students and the sponsor/client or asynchronous (e-mails, posting in a virtual classroom).

b) Depending on the structure of the course and project, the faculty member may mediate interaction between students and the clients/sponsors or students may interact directly with their clients/sponsors.

\section{Roles and Responsibilities}

The roles and responsibilities of the instructors, client/sponsor, and students vary depending on the goals, course structure, and expectations for the project.

\section{Faculty}

The faculty member's role is dependent on the nature of the project, design of the course, and needs of the students.

a) Roles: The faculty member may take on a role of facilitator or mentor.

b) Review process for students' work: The faculty member may review and/or grade students' deliverable(s) before sending them to the client, or the faculty member may rely on the client to provide the primary feedback regarding project quality and student performance.

c) Responsibility for establishing and enforcing deadlines and expectations: The faculty member may choose to enforce deadlines and ensure that client expectations are met or establish and enforce deadlines but leave it to the client/sponsor to manage the expectations for the project. 


\section{Client/Sponsor}

How much or how little involvement the client/sponsor has in the students' work depends on the structure of the projects and course goals.

a) Amount of involvement: The role of the client/sponsor could range from minimal, arms-length involvement to working closely with students on the completion of a project. When the client/sponsor is closely involved in the progress and direction of the project, the client interacts with the student/team on a regular basis and reviews each deliverable to ensure that the objectives are being addressed appropriately before students submit projects for grading.

\section{Students}

Students can be organized to accomplish the work in teams, individually, or some combination of team and individual assignments.

a) Responsibility for work product: The project may be individual, with each student completing the entirety of the work; team based, with students organized into teams to accomplish the project work; or some combination of individual and team-based work may be required. Students working individually have found it most useful to have tasks broken down into smaller parts that are due periodically rather than having an entire work product due at one time. Whether the instructor assigns roles to each member of a team or the team negotiates roles, it is most helpful to the overall progress of the project if the roles include a project manager, sponsor liaison (if allowed within the structure of the course), researcher(s), writer(s)/drafter(s), and an editor.

\section{Evaluations}

Measuring results to assess learning and the ability to apply skills and knowledge is always an important element in education.

\section{Evaluations of Students' Work}

While the faculty member is ultimately responsible for assigning grades, the faculty member may have varying degrees of input into evaluating the students' deliverables for the project.

a) Rubrics: In all cases, a rubric that outlines the performance expectations and criteria for successful project completion is important for ensuring clarity and consistency in the grading process.

b) Grading/evaluation: Determining whether the faculty member grades work before it is submitted to the client/sponsor or whether students first submit their work to the client/sponsor for feedback before grading depends on the faculty and client/sponsor definitions.

c) Student/peer evaluations: The overall grading process could include student self-evaluations and/or student peer evaluations. A relatively small percentage of the final project grade (such as 5 to $10 \%$ ) may be assigned to individual and/or peer assessments.

d) Formative vs. summative assessments: Most of the grading and feedback occurs at the end of the semester/term in summative assessments. Grading and feedback throughout the semester/term forms the basis for formative assessments of the students' work.

\section{Course/Project}

A standard feature in most educational settings is end-of-semester evaluations of a course.

a) Student opinions gathered through questionnaires are the primary source of course evaluations.

b) Clients/sponsors may also be asked to provide feedback.

\section{Faculty}

A standard feature in most educational settings is the end-of-semester evaluation of the instructional faculty.

a) Student opinions gathered through questionnaires are the primary source of course evaluations. 


\section{TESTING THE FRAMEWORK: TWO UMUC CAPSTONE COURSES}

The authors of this paper offer capstone courses in their own disciplines, biotechnology (BIOT) and public relations (PRPA), with industry/client sponsored projects. The proposed framework was tested with their courses as the first stage of testing of the framework (see tables 3 and 4). The design options selected from the framework by the BIOT and PRPA capstone course are depicted by the gray-shaded cells.

\begin{tabular}{|c|c|c|c|}
\hline Component & Elements & \multicolumn{2}{|l|}{ Capstone Course Design Options } \\
\hline \multirow[t]{10}{*}{ Projects } & Solicitation & $\begin{array}{l}\text { Students generate clients/projects } \\
\text { following established criteria }\end{array}$ & Faculty member solicits/secures projects \\
\hline & \multirow[t]{5}{*}{ Nature or Type } & \multicolumn{2}{|l|}{ Project goals align with course outcomes } \\
\hline & & $\begin{array}{lll}\begin{array}{l}\text { No financial contributions } \\
\text { client/sponsor }\end{array} & \text { from } \\
\end{array}$ & $\begin{array}{l}\text { Sponsor/client provides financial support to } \\
\text { institution, funds research, and/or pays fee }\end{array}$ \\
\hline & & $\begin{array}{l}\text { Problem based: students develop } \\
\text { proposals with or without implementation }\end{array}$ & $\begin{array}{l}\text { Results based: implementation with outcomes } \\
\text { specified by client/sponsor }\end{array}$ \\
\hline & & $\begin{array}{l}\text { Confidentiality/privacy agreement(s) not } \\
\text { required }\end{array}$ & Confidentiality/privacy agreement(s) required \\
\hline & & Client is like a customer & Sponsor is like mentor or coach \\
\hline & \multirow[t]{4}{*}{ Structure } & \multicolumn{2}{|c|}{$\begin{array}{l}\text { The project scope has well defined goals and objectives that are realistic for the length of } \\
\text { the semester(s) }\end{array}$} \\
\hline & & Individual work & Team-developed work \\
\hline & & $\begin{array}{l}\text { Competitive: similar to a request for } \\
\text { proposal (RFP) process, students } \\
\text { compete to develop winning proposal for } \\
\text { same client }\end{array}$ & $\begin{array}{l}\text { Collaborative: students work on the same or } \\
\text { independent projects, but they share ideas, } \\
\text { assist each other, and do not compete to } \\
\text { submit a winning proposal }\end{array}$ \\
\hline & & $\begin{array}{l}\text { More than one student or group works on } \\
\text { the same project }\end{array}$ & One person/team per project \\
\hline
\end{tabular}

Table 3. BIOT Project Framework Selections

\begin{tabular}{|c|c|c|c|}
\hline Component & Elements & \multicolumn{2}{|l|}{ Capstone Course Design Options } \\
\hline \multirow[t]{10}{*}{ Projects } & Solicitation & $\begin{array}{l}\text { Students generate clients/projects } \\
\text { following established criteria }\end{array}$ & Faculty member solicits/secures projects \\
\hline & Nature or Type & \multicolumn{2}{|l|}{ Project goals align with course outcomes } \\
\hline & & $\begin{array}{lll}\begin{array}{l}\text { No financial contributions } \\
\text { client/sponsor }\end{array} & \text { from } \\
\end{array}$ & $\begin{array}{l}\text { Sponsor/client provides financial support to } \\
\text { institution, funds research and/or pays fee }\end{array}$ \\
\hline & & $\begin{array}{l}\text { Problem based: students develop } \\
\text { proposals with or without implementation }\end{array}$ & $\begin{array}{l}\text { Results based: implementation with outcomes } \\
\text { specified by client/sponsor }\end{array}$ \\
\hline & & $\begin{array}{l}\text { Confidentiality/privacy agreement(s) not } \\
\text { required }\end{array}$ & Confidentiality/privacy agreement(s) required \\
\hline & & Client is like a customer & Sponsor is like a mentor or coach \\
\hline & Structure & \multicolumn{2}{|c|}{$\begin{array}{l}\text { The project scope has well defined goals and objectives that are realistic for the length of } \\
\text { the semester(s) }\end{array}$} \\
\hline & & Individual work products & Team-developed work products \\
\hline & & $\begin{array}{l}\text { Competitive: similar to a request for } \\
\text { proposal (RFP) process, students } \\
\text { compete to develop winning proposal for } \\
\text { same client }\end{array}$ & $\begin{array}{l}\text { Collaborative: students work on the same or } \\
\text { independent projects, but they share ideas, } \\
\text { assist each other, and do not compete to } \\
\text { submit a winning proposal }\end{array}$ \\
\hline & & $\begin{array}{l}\text { More than one student or group works on } \\
\text { the same project }\end{array}$ & One person/team per project \\
\hline
\end{tabular}

Table 4. PRPA Project Framework Selections 
The design of two sample graduate-level capstone courses was mapped based on the elements of the first component of the framework (table 3 ) showing how design options from column 1 or 2 , or a combination of the two can be part of the same course. One example of both options being part of the same course is confidentiality agreements (Projects---Nature/Type) in the BIOT and PRPA programs, which may or not be required depending on the needs of the client/sponsor.

\begin{tabular}{|l|l|l|l|}
\hline Component & Elements & Capstone Course Design Options \\
\hline Course & Structure & One term/semester & Two or more terms/semesters \\
\cline { 3 - 4 } & One course & Two or more courses \\
\cline { 3 - 4 } & Majority of time focused on the project & $\begin{array}{l}\text { Project time augmented with lectures, } \\
\text { discussions, and additional readings }\end{array}$ \\
\cline { 3 - 4 } & Deliverables & $\begin{array}{l}\text { Various types of assignments (research } \\
\text { paper, report, proposal, presentation, } \\
\text { quiz, exam, visual material, etc.) }\end{array}$ & $\begin{array}{l}\text { Single assignment, typically a research } \\
\text { paper, proposal, or report }\end{array}$ \\
\cline { 3 - 4 } & $\begin{array}{l}\text { Components due and graded } \\
\text { throughout semester(s) }\end{array}$ & $\begin{array}{l}\text { Majority of work due at the conclusion of } \\
\text { semester(s)/term(s) }\end{array}$ \\
\cline { 3 - 4 } & $\begin{array}{l}\text { Students incorporate grading feedback } \\
\text { into final deliverable }\end{array}$ & $\begin{array}{l}\text { Students receive informal feedback and } \\
\text { guidance without any graded components }\end{array}$ \\
\cline { 2 - 4 } & Synchronous or face-to-face environment \\
\cline { 3 - 4 } & Interaction & $\begin{array}{l}\text { Faculty member mediates interaction } \\
\text { between student and sponsor/client }\end{array}$ & $\begin{array}{l}\text { Students have direct interaction with the } \\
\text { sponsor/client }\end{array}$ \\
\hline
\end{tabular}

Table 5. BIOT Course Framework Selections

\begin{tabular}{|c|c|c|c|}
\hline Component & Elements & Capstone Course Design Options & \\
\hline \multirow[t]{8}{*}{ Course } & \multirow[t]{3}{*}{ Structure } & One term/semester & Two or more terms/semesters \\
\hline & & One course & Two or more courses \\
\hline & & Majority of time focused on the project & $\begin{array}{l}\text { Project time augmented with lectures, } \\
\text { discussions, and additional readings }\end{array}$ \\
\hline & \multirow[t]{3}{*}{ Deliverables } & $\begin{array}{l}\text { Various types of assignments (research } \\
\text { paper, report, proposal, presentation, } \\
\text { quiz, exam, visual material, etc.) }\end{array}$ & $\begin{array}{l}\text { Single assignment, typically a research } \\
\text { paper, proposal, or report }\end{array}$ \\
\hline & & $\begin{array}{l}\text { Components due and graded } \\
\text { throughout semester(s) }\end{array}$ & $\begin{array}{l}\text { Majority of work due at the conclusion of } \\
\text { semester(s)/term(s) }\end{array}$ \\
\hline & & $\begin{array}{l}\text { Students incorporate grading feedback } \\
\text { into final deliverable }\end{array}$ & $\begin{array}{l}\text { Students receive informal feedback and } \\
\text { guidance without any graded components }\end{array}$ \\
\hline & \multirow[t]{2}{*}{ Interaction } & Asynchronous environment & Synchronous or face-to-face environment \\
\hline & & $\begin{array}{l}\text { Faculty member mediates interaction } \\
\text { between student and sponsor/client }\end{array}$ & $\begin{array}{l}\text { Students have direct interaction with the } \\
\text { sponsor/client }\end{array}$ \\
\hline
\end{tabular}

Table 6. PRPA Course Framework Selections

The BIOT and PRPA capstone courses use similar design options for the Course component. The difference is in the types of assignments required as deliverables and the nature of interaction between the three stakeholders. In BIOT, students/teams have direct interaction with the sponsor, while in PRPA, the faculty member mediates the interaction between student/teams and the client.

The differences in design between the BIOT and PRPA courses in terms of roles and responsibilities of the students, faculty, and client/sponsor is significant, as illustrated in tables 7 and 8 . The evaluation selections are also provided in these tables.

\begin{tabular}{|l|l|l|ll|}
\hline Component & Elements & Capstone Course Design Options & \\
\hline $\begin{array}{l}\text { Roles and } \\
\text { Responsibilities }\end{array}$ & Faculty & Facilitator & Mentor & \\
\cline { 3 - 5 } & $\begin{array}{l}\text { Reviews work before final submission to } \\
\text { the client }\end{array}$ & $\begin{array}{l}\text { Provides general guidance } \\
\text { student/teams }\end{array}$ & to \\
\cline { 3 - 5 } & Establishes and enforces class assignment & Establishes and enforces deadlines but \\
\hline
\end{tabular}




\begin{tabular}{|c|c|c|c|}
\hline & & deadlines and client expectations & client manages own expectations \\
\hline & $\begin{array}{l}\text { Client/ } \\
\text { Sponsor }\end{array}$ & $\begin{array}{l}\text { Arms-length from students or interacts } \\
\text { minimally with students directly }\end{array}$ & $\begin{array}{l}\text { Works directly/closely with students, } \\
\text { including regular meetings and feedback }\end{array}$ \\
\hline & Students & $\begin{array}{l}\text { Each individual student is responsible for } \\
\text { all elements of the project }\end{array}$ & $\begin{array}{l}\text { Students work in teams with defined team } \\
\text { member roles (assigned or team member } \\
\text { negotiated) }\end{array}$ \\
\hline \multirow[t]{7}{*}{ Evaluations } & \multirow{5}{*}{$\begin{array}{l}\text { Students' } \\
\text { Work }\end{array}$} & \multicolumn{2}{|l|}{ Grading rubrics } \\
\hline & & $\begin{array}{l}\text { Faculty member reviews work before } \\
\text { students' proposals are submitted to the } \\
\text { client/sponsor }\end{array}$ & $\begin{array}{l}\text { Client/sponsor reviews students' work } \\
\text { before it is submitted for grading }\end{array}$ \\
\hline & & Faculty grading & Client/sponsor evaluations \\
\hline & & Students submit self-evaluation & Team member evaluations \\
\hline & & Formative & Summative \\
\hline & $\begin{array}{l}\text { Course } \\
\text { Project }\end{array}$ & Student evaluations using questionnaires & $\begin{array}{ll}\text { Client/sponsor } & \text { evaluations } \\
\text { questionnaires }\end{array}$ \\
\hline & Faculty & Student evaluations using questionnaires & $\begin{array}{l}\text { Client/sponsor } \\
\text { questionnaires }\end{array}$ \\
\hline
\end{tabular}

Table 7. BIOT Roles and Responsibilities and Evaluation Framework Selections

\begin{tabular}{|c|c|c|c|}
\hline Component & Elements & \multicolumn{2}{|l|}{ Capstone Course Design Options } \\
\hline \multirow{5}{*}{$\begin{array}{l}\text { Roles and } \\
\text { Responsibilities }\end{array}$} & \multirow[t]{3}{*}{ Faculty } & Facilitator & Mentor \\
\hline & & $\begin{array}{l}\text { Reviews work before final submission to } \\
\text { the client }\end{array}$ & $\begin{array}{lll}\begin{array}{l}\text { Provides general guidance } \\
\text { student/teams }\end{array} & \text { to } \\
\end{array}$ \\
\hline & & $\begin{array}{l}\text { Establishes and enforces class assignment } \\
\text { deadlines and client expectations }\end{array}$ & $\begin{array}{l}\text { Establishes and enforces deadlines but } \\
\text { client manages own expectations }\end{array}$ \\
\hline & $\begin{array}{l}\text { Client/ } \\
\text { Sponsor }\end{array}$ & $\begin{array}{l}\text { Arms-length from students or interacts } \\
\text { minimally with students directly }\end{array}$ & $\begin{array}{l}\text { Works directly/closely with students, } \\
\text { including regular meetings and feedback }\end{array}$ \\
\hline & Students & $\begin{array}{l}\text { Each individual student is responsible for } \\
\text { all elements of the project }\end{array}$ & $\begin{array}{l}\text { Students work in teams with defined team } \\
\text { member roles (assigned or team member- } \\
\text { negotiated) }\end{array}$ \\
\hline \multirow[t]{7}{*}{ Evaluations } & \multirow{5}{*}{$\begin{array}{l}\text { Students' } \\
\text { Work }\end{array}$} & \multicolumn{2}{|l|}{ Grading rubrics } \\
\hline & & $\begin{array}{l}\text { Faculty member reviews work before } \\
\text { students' proposals are submitted to the } \\
\text { client/sponsor }\end{array}$ & $\begin{array}{l}\text { Client/sponsor reviews students' work } \\
\text { before it is submitted for grading }\end{array}$ \\
\hline & & Faculty grading & Client/sponsor evaluations \\
\hline & & Students submit self-evaluation & Team member evaluations \\
\hline & & Formative & Summative \\
\hline & $\begin{array}{l}\text { Course } \\
\text { Project }\end{array}$ & Student evaluations using questionnaires & $\begin{array}{l}\text { Client/sponsor } \\
\text { questionnaires }\end{array}$ \\
\hline & Faculty & Student evaluations using questionnaires & $\begin{array}{l}\text { Client/sponsor } \\
\text { questionnaires }\end{array}$ \\
\hline
\end{tabular}

Table 8. PRPA Roles and Responsibilities and Evaluation Framework Selections

\section{DISCUSSION}

The research is generally consistent regarding the reasons for offering capstone courses that include reallife projects offered by industry partners for students $[2,3,4,5,8,12,13,14]$. The real question then, is what drives the decisions in the construction of the capstone course?

The first consideration is how to ensure a course involving industry partners offers experiential learning opportunities that are appropriately aligned with the mission and goals of the institution and the specific academic program. Since the intent of this type of capstone course is to provide students with meaningful, portfolio-worthy demonstrations of the knowledge and skills they have gained throughout their courses of study, the curriculum preceding the capstone must provide the necessary foundation for successful performance in the capstone course. 
The second consideration is the availability of resources, both in terms of faculty/institutional support and a pool of potential clients. Capstone courses, particularly those that incorporate industry partners, are especially demanding on faculty because of the often intense engagement the faculty member must have throughout the process. Available and interested faculty who are committed to the course demands are essential. Depending on the size of the program and numbers of students participating in a given capstone course, more than one instructor may be needed.

Securing projects can be a time consuming process unless a program has a pool of potential clients/sponsors or consistent participation from existing clients/sponsors. Assessing the ongoing availability of industry partners is critical to developing a sustainable capstone program that uses these types of projects. For programs with large numbers of students, decisions about course structure and whether multiple students can work on a single project determines the number of industry projects needed for a capstone course. For example, the biotechnology master's degree program at UMUC has approximately 475 students. The course is structured to assign one team of students (4-5 members) to one project. This means that the program requires several projects each semester. In the spring 2013 semester, this program offered three sections of the capstone course with a total of 68 students. Based on the model used, the program manager secured 17 projects to accommodate all of the sections and students.

The public relations program is smaller (approximately 250 students) and is structured differently. Depending on students' interests, they can either identify and develop a project for their own client or work individually to develop competitive proposals in response to a pre-selected client's problem statement. This process is designed to mirror the request for proposal (RFP) process that is common in the industry. With this course design flexibility, fewer industry partners are required for each semester. For example, in the spring 2013 semester, there was one section of the capstone course with 21 students enrolled. Several students elected to work on one client project while other students identified their own client projects.

The framework presented here is intended to allow educators to see the variety of options available in designing a capstone course that uses industry-sponsored projects. The framework identifies key variables and allows educators to pick and choose elements that make the most sense for the program, the students, and the goals established for the course.

\section{CONCLUSION}

Increasingly, capstone courses are becoming an integral and necessary part of graduate education, particularly in online academic programs. Significant educational and professional benefits are created from offering experiential learning opportunities that include industry-sponsored capstone projects in culminating courses.

The framework proposed here should address the needs of a range of capstone course designs. Framework testing in two diverse capstone courses offered the first validation of this model. However, additional research is needed to test and refine the framework to ensure it is inclusive of the range programs that can include a capstone experience.

\section{ABOUT THE AUTHORS}

Rana Khan is a professor and Chair of the Information and Technology Systems department at the University of Maryland University College. She is also the director of Professional Science Master's program in Biotechnology. She has published articles on integrating industry-sponsored projects in online capstone courses and designing and implementing an E-mentoring program for online graduate students. Prior to her work in online education, she was a research scientist. She holds a Ph.D. in Cell and Molecular Biology from the University of Maryland at College Park. 
Julie Hill is a professor and director of the Public Relations Program in the Graduate School of the University of Maryland University College. Prior to her appointment there, she spent most of her career in local government and law enforcement public affairs. She is co-author of the book, Strategic

Communication Practices: A Toolkit for Law Enforcement Executives, published by the DOJ/COPS office in 2012. Julie earned an undergraduate degree from Emerson College in Boston, Massachusetts, and her M.S. and Ph.D. from Bowling Green State University in Ohio.

\section{REFERENCES}

1. Kelly, R. Capstone Courses Prepare Students for Transition to Working World. Academic Leader, 22(2): 8 (2006).

2. Farr, J., Lee, M., Metro, R., and Sutton, J. Using a Systematic Engineering Design Process to Conduct Undergraduate Engineering Management Capstone Projects. Journal of Engineering Education: 193-197 (2001).

3. Aller, B.M., Kline, A.A., and Tsang, E. Work in progress: Improving the Senior Capstone Design Experience through Shared Perspectives and Best Practices. 34th ASEE/IEEE Frontiers in Education Conference, Savannah, GA (October 20-23, 2004).

4. Bruhn, R.E., and Camp, J. Capstone Course Creates Useful Business Products and Corporate-ready Students. Inroads-The SIGCSE Bulletin, 8, 36(2): 89-92 (2004).

5. Gorka, S., Miller, J.R., and Howe, B.J. Developing Realistic Capstone Projects in Conjunction with Industry. SIGITE: 27-31 (2007).

6. Berheide, C.W. Doing Less Work, Collecting Better Data: Using Capstone Courses to Assess Learning. Peer review 9 (2) (2007).

7. Clark, E., Engel, D., Napolitano, M., Richardson, J., Rodriquez, M., Sterling-Deer, C., and Kasprzak, C. Integration Reflection, Closure \& Transition Advancing Capstone Learning at LaGuardia. Report of the Faculty Research Team on Capstone Education (November 15, 2008).

8. Gorman, M.F. The University of Dayton Operations Management Capstone Course: Undergraduate Student Field Consulting Applies Theory to Practice. Interfaces 40(6): 432-443 (2010).

9. Bojanova, I., and Khan, R. Designing Online Capstone Courses in Partnership with Industry. Paper presented at the $26^{\text {th }}$ Annual Conference on Distance Teaching \& Learning (August 4-6, 2010).

10. Goold, A. Providing Process for Projects in Capstone Courses. Paper presented at the ITiCSE Conference, Thessaloniki, Greece (2003).

11. Adams, L., Daniels, M., Goold, A., Hazzan, O., Lynch, K., and Newman, I. Challenges in Teaching Capstone Courses. Paper presented at the ITiCSE Conference, Thessaloniki, Greece (2003).

12. Goldberg, J., Cariapa, V., Corliss, G., and Kaiser, K. The Benefits of Industry Involvement in the Multidisciplinary Capstone Design Course at Marquette University. Paper presented at the Capstone Design Conference 2012, Aurora, CO (2012).

13. Hagan, L.M. Fostering Experiential Learning and Service through Client Projects in Graduate Business Courses Offered Online. American Journal of Business Education, 5(5): 623-632 (2012).

14. Estell, J.K., and Hurtig, J.K. Adopting Best Corporate Practices for Capstone Courses. Paper presented at the Capstone Design Conference 2012, Aurora, CO (2012).

15. Nassersharif, B., and Riley, L.A. Some Best Practices in Industry-sponsored Capstone Design Projects. Paper presented at the Capstone Design Conference 2012, Aurora, CO (2012).

16. Conroy, R., and Khan, R. Integrating Virtual Internships into Online Classrooms. Journal of Commercial Biotechnology, 15: 97-11 (2009).

17. Allen, I.E., and Seaman, J. Going the Distance: Online Education in the United States. Wellsley, MA: Babson Survey Research Group and Quahog Research Group, LLC (2011). 